\title{
Five Attempts to Serve Adult Education in University Library
}

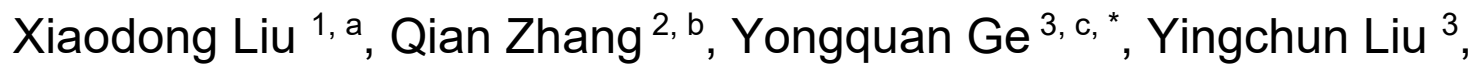 \\ Shuyuan $\mathrm{Liu}^{4}$, Wei He ${ }^{5}$ \\ 1. College of Continuing Education, Shandong Jianzhu University, Jinan, China \\ 2. Office of Jijian, Shandong Education TV, Jinan, China \\ 3. College of Surveying and Geo-Informatics, Shandong Jianzhu University, Jinan, China \\ 4. College of Humanities, Shandong Agricultural and Engineering University, Jinan, China \\ 5. Shandong Jianzhu University, Jinan, China \\ alluxd123456@sdjzu.edu.cn, b1368698236@qq.com, c, " ge39953@163.com
}

\begin{abstract}
According to the characteristics of adult higher education, this paper expounds the necessity of cultivating the information quality of adult students. This paper gives full play to the functions of university library, and combined with practical measures, puts forward some effective ways for university library to implement adult education service.
\end{abstract}

Keywords: University Library; Adult Education; Adult Students; Information Literacy Education; Digital Library.

\section{Introduction}

Adult education is a form of education different from general education. It is a form of education that focuses on self-study and supplemented by face-to-face teaching. As early as 1995, China promulgated the "Education Law" which stipulates that "lifelong education system should be established", which establishes the status of lifelong education in law [1]. The learning of adult education students is characterized by various levels, scattered majors, short school time and relatively concentrated class time [2]. As the center of knowledge and information, University Library shoulders the important task of information transmission according to its learning characteristics, and adopts effective service means and ways to meet the information needs of adult education students. Through several years of library service for adult education students, the author has made the following attempts, and has received good results, it is summarized as follows.

\section{Five Attempts}

\subsection{Cultivate Adult Education Students' Information Skills and Improve Their Information Quality}

In the network environment, information resources can be called massive, in order to find the information they need, it is impossible to do without mastering certain means and methods. Therefore, it is necessary to improve the information quality of adult students, cultivate the skills of obtaining information and master the means of information retrieval. The so-called information quality refers to the basic ability of people to search, obtain information and process, organize and use the information[3]. To cultivate the information quality of adult education students is to increase their "hematopoietic function", so that they have stronger practical ability and can use the knowledge they have learned to analyze and solve the practical problems they encounter.

Information retrieval course should be added to adult education. In the aspect of teaching arrangement, according to the characteristics of adult students, we should formulate the teaching syllabus and arrange the teaching content reasonably; in the aspect of teaching content, we should adapt to the development speed of network resources. In the part of introduction to information, we mainly teach information and other related basic concepts, information retrieval language, retrieval 
methods and ways; in the part of database utilization, we mainly focus on the latest network academic resources introduced by the library Database, to academic journal full-text, Dissertation Full-text, science and technology academic conference full-text, patent, standard and other information resources access and retrieval skills; in the Internet information retrieval part, mainly focus on the Chinese and foreign language main search engine retrieval methods of academic information. In terms of teaching methods and means, it is necessary to break the traditional teacher centered indoctrination teaching method and realize an active new teaching method combining teacher guidance and students' autonomous learning. It is not only to improve adult students' self-study ability and independent operation ability, but also to cultivate adult students' independent thinking and judgment ability. Adult students are no longer passive to accept knowledge, but become the master of learning. Teachers play a leading role in the process of students' learning, encourage adult students to learn individually, make the teaching of retrieval course become the exploration process of students' independent analysis and problem-solving under the guidance of teachers, and cultivate students' thinking ability, scientific research ability and innovation ability. Information systems (e.g. e-mail box, personal webpage, subject website, institutional information system, business information management system, etc.) are increasingly connected in the same cyberspace. Various information processing mechanisms based on network, knowledge and cooperation are becoming more and more mature, and the link, exchange, interoperability, cooperation and integration between them are becoming increasingly possible. The digital library has developed from the original digital library based on digital resources to the digital library based on integrated information services, and now it has developed into the digital library based on user information activities[1]. Their architectures are shown in Figure 1, figure 2 and figure 3 respectively.

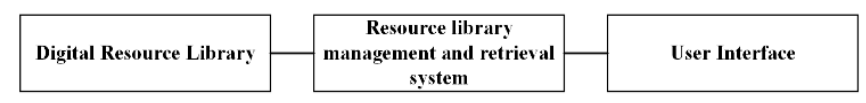

Fig 1. The digital library based on digital resources

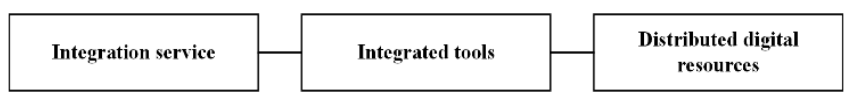

Fig 2. The digital library based on integrated information services

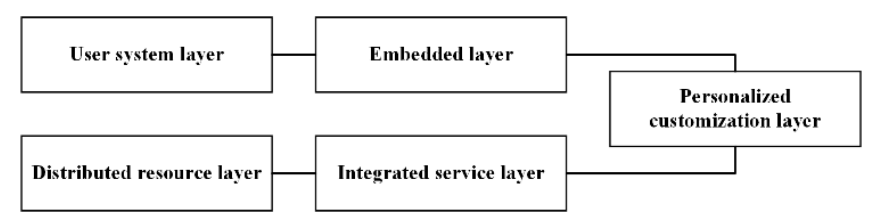

Fig 3. The digital library based on user information activities

\subsection{Revealing Various Resources of Library to Adult Education Students}

Due to the fact that adult education students seldom go to the library at ordinary times and know little about the library collection resources, various databases and various virtual resources on the Internet, they often feel helpless to obtain the information they need from them[4]. First of all, we should strengthen the propaganda of information resources in university libraries Through various publicity channels, we can strengthen the publicity of information resources of university library, let adult education students understand the information resources of university library, arouse their awareness of information resources, make everyone fully realize the importance of information resources, stimulate adult education students' readers' demand for information resources to the maximum extent, and promote the use of information resources. For example, the university library can communicate with readers and answer the consultation by means of readers online, QQ online consultation, readers' message and e-mail, so as to strengthen the online publicity service and give play to the interactivity and interactivity of information resources publicity. Through the all-round 
propaganda of the information resources of university library, the adult education students can have an all-round understanding of the information resources. Secondly, it is necessary to introduce to adult education students the library's collection layout, collection characteristics, rules and regulations, and the borrowing process and regulations of books and materials.

\subsection{Strengthen the Construction of Information Resources and Optimize the Structure of Resource Collection}

In the network age, the application of network technology and information exchange are increasingly widespread [5]. The service object of university library is not limited to the campus, but the whole network users. From the perspective of serving adult education, in the construction of information resources in university libraries, we should not only scientifically select the types of resources, but also coordinate the construction of different types of resources, such as traditional printed literature information and digital information resources, At the same time, we should make full use of and further consolidate and develop the relationship of document information resources sharing and cooperation among libraries, so as to break the regional restrictions of adult education.

\subsection{Building the Network Environment of Adult Education}

Website is not only the connecting point between University Library and readers, but also the best way for university library to serve adult education[6]. As the connection point, the website must be able to give readers the latest information. Through the subject navigation system, the university libraries, foreign university libraries, search engines, websites, bibliographic databases, etc. can be linked to the Internet. In addition, through the development of remote login access system function, set up remote access resources, video on demand, etc. With the rapid development of digital construction of University Libraries in China, university libraries should continue to increase the pace of network digital construction and create a network environment for adult education.

\subsection{Adult Education Students and Full-time Students Enjoy the Same Information Services}

Most university libraries in China adopt the library and reading room management service mode, which integrates collection, borrowing, reading, consulting, checking and network services, so that adult students and Full-time students can enjoy the library's "one card service"[7]. The so-called library "one card service" refers to: after readers enter the library with documentary evidence, they can freely enter each library, reading room, self-study area to borrow books, periodicals, browse newspapers, self-study, go to the multimedia reading room to enjoy multimedia courseware, consult, query, search online database, download various documents, pictures, copy and print the required information Materials, etc. Here, adult students and Full-time students can share the library's rich literature resources, good learning environment and academic atmosphere

\section{Summary}

To sum up, the service of University Library for adult education is the inevitable requirement of social development. As long as we grasp the law of adult education, constantly explore new ways and methods of serving adult education, adapt to the development process of the situation, and give full play to the advantages of university library, we can make adult education receive actual effect in the use of library, and the library will also play its great role The role of the government.

\section{References}

[1] X. L. Zhang, "The Paradigm Evolution and Challenges of Digital Library Mechanism," Journal of Library Science in China, pp. 3-8+17, 2001.

[2] W. C. Du, Information acquisition and utilization: Tsinghua University Press, 2016.

[3] H. H. Lin, Information Resource Retrieval and Utilization: Electronic Industry Press, 2008. 
[4] F. Li, "How University Libraries Serve Adult Education," Science and Technology Information, p. 307, 2009-01-15 2009.

[5] S. J. Liu, S. Q. Tai and Q. F. Li, "Cognition and Thinking on the Information Literacy Education of Adult Students," China Adult Education, pp. 109-110, 2009-02-15 2009.

[6] Y. Tian, "Countermeasures for Improving the Service Function of Adult Education in University Library," China Adult Education, pp. 77-78, 2007-03-30 2007.

[7] C. Y. Chang, "The Information Literacy Education of University Library and Adult Students," China Adult Education, pp. 60-61, 2005-10-28 2005. 